\title{
A Framework for Environmental Mitigation in Convention and Exhibition Centers in the China Greater Bay Area
}

\author{
Author \\ Prof. Wilco Chan, Technological and Higher Education Institute of Hong Kong \\ Dr. Barry Mak, The Hong Kong Polytechnic University \\ Dr. Derrick Lee, The Hong Kong Polytechnic University \\ Dr. Carol Zhang, University of Portsmouth
}

\begin{abstract}
The numerous participants in convention and exhibition (C\&E) events and the consequently huge consumption of direct and indirect resources have increased the environmental pressure on $C \& E$ centers to implement environmentally friendly practices and procedures. This paper explores the innovative methods adopted by green-certified $\mathrm{C} \& \mathrm{E}$ centers and synthesizes a reference framework of environmental mitigation practices for the $\mathrm{C} \& \mathrm{E}$ sector in the Greater Bay Area, which was recently designated as a major regional development area in China. Eleven green-certified $\mathrm{C} \& \mathrm{E}$ centers were selected to establish a comprehensive and indicative framework containing 59 actual environmental practices in three major categories. Suggestions made by 12 experts for modifying the fit of the constructed framework to suit the local geographical and climatic situations of C\&E centers in the China Greater Bay Area were examined.
\end{abstract}

Keywords: China Greater Bay Area, Convention and Exhibition, environmental initiatives, corporate social responsibility, environmental mitigation, reference framework 


\section{Introduction}

In 2005 , the tourism sector contributed $5 \%$ of total global carbon dioxide emissions and $14 \%$ of total global greenhouse gases, according to a report by Scott, Peeters, and Gossling (2010). Tourist transportation accounted for approximately three quarters of the sector's carbon dioxide emissions, and accommodation took up 20\%. The same report projected that the tourism sector's share of global carbon dioxide emissions would increase to $7 \%$ by 2035 .

The convention and exhibition (C \& E) industry has experienced rapid growth in recent decades globally such as an increase in annual turnover, exhibition venues and spaces, higher number of visitors to 31,000 exhibitions worldwide, particularly in United States, China and Germany (UFI, 2014; 2017). China contributed $60 \%$ of Asia's total C\&E space and is ranked sixth among Asian C\&E venues (Chen, 2009; Lu \& Cai, 2011). Many provincial governments attracted big-spending investors and this led to an increase in the number of $\mathrm{C} \& \mathrm{E}$ centers from 3.22 million square meters in 2003 to 118 million square meters in 2015 . There were 1,385 exhibitions with a total net exhibition space of 639,000 square meters (Department of Trade in Services, 2016).

It is observed that the current green management methods deployed by most $\mathrm{C} \& \mathrm{E}$ centers should be more comprehensive and proactive to mitigate environmental issues such as the huge consumption of water, energy, and other resources (UFI, 2017). The 
environmental degradation is more severe particularly in Asia due to the lack of awareness on the importance of environmental sustainability among stakeholders. It is important to raise awareness and to take appropriate environmental actions. The green methods implemented by $\mathrm{C} \& \mathrm{E}$ centers with green certification in developed economies can provide valuable models for $\mathrm{C} \& \mathrm{E}$ centers in developing nations to adopt.

In March 2017, Keqiang Li, Premier of the People's Republic of China, announced the establishment of the Guangdong-Hong Kong-Macao Greater Bay Area (GBA), serving as the catalyst for urbanization in China. The main purpose of establishing this cluster was to accelerate the growth of less developed cities in the GBA to leverage the power of first-tier cities (Lee, 2017). Eleven cities are included in China's GBA: Hong Kong, Macau, Guangzhou, Shenzhen, Zhuhai, Foshan, Zhongshan, Huizhou, Dongguan, Zhaoqing, and Jiangmen, with a total combined area of 56,500 square kilometers. The major C\&E centers in the GBA, with a total floor space of more than 360,000 square meters, are important to the development process as a whole. Given the GBA's massive C\&E space, innovative environmental mitigation methods for the area's environmental issues are urgently required. Existing environmental methods adopted by green-certificated $\mathrm{C} \& \mathrm{E}(\mathrm{GCC} \& \mathrm{E})$ centers are envisaged to be particularly useful to $\mathrm{C} \& \mathrm{E}$ center operators. A website search reveals a paucity of environmental information except in the official websites of GCC\&E centers in Hong Kong. 
Sustainability and environmental concerns have been well studied in tourism research. However, limited research has focused on energy consumption in the MICE industry. These studies have focused mainly on specific C\&E venues (Chen, 2009; Lu, \& Cai, 2011; Spiller 2002). Previous studies, therefore, may have overlooked holistic environmental mitigation efforts in the $\mathrm{C} \& \mathrm{E}$ industry.

In view of the global sustainability trend and the foreseeable increase in environmentalist pressure on the operations of C\&E centers, this study had three specific objectives, as follows.

1) Synthesize a reference framework for environmental mitigation practices undertaken by $\mathrm{C} \& \mathrm{E}$ centers.

2) Identify innovative methods used by GCC\&E centers.

3) Modify the reference framework of environmental mitigation practices to fit C\&E centers in China's GBA.

\section{Literature review}

With the expansion of the tourism industry worldwide, tourism is increasingly exacerbating climate change. This is mainly because the operation of tourism requires a lot of fossil fuels (Gossling \& Svensson, 2006). Within the tourism industry, transportation, accommodation, and tourist attractions are the top three sources of energy consumption (Becken, Simmons, \& Frampton, 2003). Other studies have argued that to provide a comprehensive on-site energy consumption evaluation, one 
must consider these three sectors (Dubois \& Ceron, 2006; Kelly \& Williams, 2007).

As an emerging tourism sector, $\mathrm{C} \& \mathrm{E}$ plays an increasingly significant role in the tourism industry (Spiller, 2002). The earliest document addressing the environmental degradation caused by the C\&E industry can be traced to an official study conducted by the U.S. Environmental Protection Agency (EPA) in 2000 (U.S. EPA 2000). The EPA confirmed that conventions consume more energy than any other leisure activity. After energy, the second most consumed item is water. Conference participants, who travel frequently, depend on hotels, where they use more water than at home. The EPA's report also noted that conferences generate more waste than activities in other tourism sectors (U.S. EPA, 2000). For example, during a typical five-day conference, “2,500 attendees use 62,500 plates, 87,500 napkins, 75,000 cups or glasses and 90,000 cans or bottles." These striking waste statistics do not yet accommodate paper waste or transportation emissions (Meeting Strategies Worldwide, 2006).

Within C\&E studies, economic impacts, social impacts, and destination marketing have acquired wider academic attention. A handful of researchers, such as Becken (2002b), Høyer and Naess (2001), and Law (2004), have explored the impact of the convention sector on the environment. Høyer and Naess (2001) cautioned that conference tourism produces abundant $\mathrm{CO}_{2}$ because of the air travel of conference tourists, and that emissions released at high altitudes have a larger climatic impact than the same amount of greenhouse gases emitted closer to the ground: up to 2.7 
times greater, according to the Intergovernmental Panel on Climate Change (IPCC, 1999).

Further, because of the extended air travel distance involved in attending conventions, the convention sector has been found to generate the highest level of greenhouse gas emissions per trip in comparison with other tourism sectors (U.S. EPA, 2000). The Travel Industry Association of America (2004) reported that $32 \%$ of business trips have flight components, of which $22 \%$ are designated primarily for conventions, conferences, or seminars.

With such excessive consumption, some convention centers have already adopted several environmental mitigation methods. The list of environmental mitigation methods is not exhaustive; nor has a holistic environmental improvement framework specific to $\mathrm{C} \& \mathrm{E}$ center operators been constructed. Trade councils have developed portals and advertising programs for sustainable events and independent certification, as well as highlighting some cases with best practices (Green Meeting Industry Council, 2017; UFI, 2017).

This type of comprehensive environmental assessment framework is already available in the lodging sector for operators' reference. Green Globe 21, Hotel Building Environmental Assessment Scheme (HBEAS), ECOTEL, etc., are known as "environmental assessment methods" (EAMs). All EAMs have common objectives 
for hotel management in providing operational guidelines and assessment criteria to deal with environmental problems. According to Lo et al. (2013), an EAM is an accreditation agency that awards credits or points according to a list of criteria to encourage green practices in different sectors.

Once a hotel has succeeded in such an assessment, an "eco-label" is awarded to create a green image of the organization. However, EAMs vary; some have a few attributes and others over 100 attributes. Lo et al. (2014) compared three EAMs used in the hotel sector, namely Green Globe 21, HBEAS, and Green Hotel Certification. Through qualitative content analysis, Lo et al. (2014) divided 61 assessment attributes into nine key environmental categories, namely general issues, energy-related issues, water-related issues, solid waste related issues, green purchases, building services systems, hotel designs, indoor environmental quality, and pollution and emissions. They further argued that these nine categories are common attributes to consider when dealing with environmental evaluation.

In the tourism subsector, the airline sector adopted an assessment framework to analyze the reported commitment of some airlines in the Asia-Pacific region and Europe. The framework originated from environmental accounting and comprises 16 environmental categories (Chan \& Mak, 2005; Mak et al., 2007). Categories 1 and 2 concern the company's commitment to environmental improvement. Categories 3-8 are about the airline's systems of environmental improvement. Categories 9-15 are 
related to specific improvement aspects. Category 16, "plans and targets," gauges the airline's commitment to continuous improvement to meet the set target. Four classes of components, namely "core," "important," "add-on," and "developing," were proposed according to the frequency of different elements in the airlines' reports.

Stakeholders and local communities have increasingly high expectations of corporate environmental commitment and endeavor. The above review indicates that companies in the mainstream building sector and tourism subsectors, such as hotels and airlines, are actively and progressively pursuing environmental improvement and assessment. However, a paucity of information is available on environmental assessment in the C\&E sector.

\section{Research methods}

This study adopted a qualitative approach, with an emphasis on 1) identifying views on environmental issues in the C\&E sector and the reasons for these views; and 2) obtaining in-depth insights into the development of innovative and applicable environmental mitigation practices (Walsh, 2003).

\section{Phase 1}

The investigation was divided into two phases. The first phase involved the collection of information on green methods undertaken by $\mathrm{C} \& \mathrm{E}$ centers that received environmental certification and/or conservation awards. C\&E centers in developed 
countries/economies with green certifications such as Green Globe, LEED Gold Certification, Gold certification, and the BCA Green Mark Platinum Award were eligible for inclusion in the study. After three rounds of searching in the U.S., Europe, Australia, and Asia, $11 \mathrm{C} \& E$ centers (three in the U.S., three in Europe, three in Asia, and two in Australia) were shortlisted for the study. Eleven C\&E centers were believed to constitute a representative sample for this qualitative study that accurately reflected the entity. Table 1 depicts the characteristics of the selected C\&E centers.

Table 1. Characteristics of the Studied Convention Centers

\begin{tabular}{|c|c|c|c|c|c|}
\hline Convention Center & Size $\left(\mathrm{m}^{2}\right)$ & $\begin{array}{l}\text { Year of } \\
\text { opening }\end{array}$ & $\begin{array}{l}\text { Capacity } \\
\text { (persons) }\end{array}$ & $\begin{array}{lr}\begin{array}{l}\text { No. } \\
\text { events } \\
\text { year }\end{array} & \text { per } \\
\end{array}$ & $\begin{array}{l}\text { Level of green } \\
\text { certification }\end{array}$ \\
\hline $\begin{array}{llll}\text { MCEC } & \text { (Melbourne } & \text { Convention } & \text { Exhibition } \\
\text { Center) } & & \\
\end{array}$ & 70,000 & 1996 & 7,500 & $>1,000$ & EarthCheck Gold \\
\hline $\begin{array}{l}\text { LACC (Los Angeles Convention Exhibition } \\
\text { Center) }\end{array}$ & 67,000 & 1971 & 152,00 & Around 150 & Green Globe Gold \\
\hline MCC (Minneapolis Convention Center) & 43,000 & 1990 & 22,000 & Around 70 & $\begin{array}{l}\text { Green } \\
\text { Certified }\end{array}$ \\
\hline SDCC (San Diego Convention Center) & 90,000 & 1989 & 125,00 & Around 110 & Green Globe Gold \\
\hline ECL (ExCel, Exhibition Center London) & 87,328 & 2000 & 68,750 & Around 300 & $\begin{array}{l}\text { ISO14001 and } \\
\text { ISO20121 }\end{array}$ \\
\hline DCC (Darwin Convention Center) & 22,900 & 2008 & 5,200 & 153 & Green Globe 21 \\
\hline $\begin{array}{l}\text { HKCEC (Hong Kong Convention and Exhibition } \\
\text { Center) }\end{array}$ & 92,000 & 1988 & 20,000 & 1,113 & LEED Gold \\
\hline SE (Singapore Expo) & 100,000 & 1999 & 19,000 & 800 & $\begin{array}{l}\text { BCA Green Mark } \\
\text { Platinum }\end{array}$ \\
\hline MBEC (Messe Bremen Exhibition Center) & 40,000 & 1963 & 14,000 & 54 & "Climate Friend" \\
\hline ITCP (International Trade Center Paris) & 320,000 & 2016 & $>10,000$ & 500 & LEED Gold \\
\hline AWE (Asia World Expo) & 70,000 & 2005 & 14,000 & 300 & $\begin{array}{l}\text { Green Organization } \\
\text { Label }\end{array}$ \\
\hline
\end{tabular}

The online portals of the centers were evaluated by checking for the keywords "green," "environment," and "C\&E center" to acquire environmental information. A pre-existing hotel environmental assessment framework (Lo, Chan, \& Zhang, 2013) was adapted to establish categorical headings for a checklist of the identified green methods. After an analysis of the pre-existing hotel environmental assessment framework, the headings "renewable energy" and "air quality" were extracted from the category "Others" as standalone categories. Eleven categories of environmental mitigation were formed as the basis for analysis and referencing. 
Content analysis was conducted to identify the green methods used by the centers, which were differentiated based on the percentage of adoption by individual centers relative to the total number of studied centers. Five types of components were demarcated in the framework, with reference to and adaptation of practices in previous studies (Chan \& Mak, 2005; Mak and Chan, 2006). "Core” components (CC) refer to methods adopted by $91 \%-100 \%$ of the selected centers, "popular" (PC) by $71 \%-90 \%$ of the studied centers, "growing" (GC) by $31 \%-70 \%$ of the selected centers, "developing" (DC) by 11\%-30\% of the studied centers, and "innovative" (IC) by $1 \%-10 \%$ (that is, by one or two centers in this survey). The low occurrence of green methods in the sector suggests that such methods are highly innovative.

Two assistants, who had completed degrees in environmental studies, were trained with environmental assessment materials published by scholars and building councils in the hotel and building sectors (Mak et al., 2013; Teng et al., 2012; Chan, 2009; U.S. Building Council, 2017). The assistants were briefed about the search and data recording processes, including entering the identified environmental methods into a rubric matrix used in the reported environmental assessment framework developed by Lo et al. (2014).

The assistants' search results were reconciled with each other. If any differences arose between their initially checked results, the two investigators revisited the 
websites to reach a consensus on the examined results. To sort out the specificities of environmental assessment of C\&E centers, methods that differed from the above 59 assessment attributes were considered potential environmental categories specific to the C\&E business.

As the reference framework was established principally using overseas C\&E centers, the developed framework may have failed to accommodate local variations in China's GBA. Thus, the second phase consisted of conducting interviews with environmental experts to elicit their recommendations for additional mitigation methods tailored to the context of China's GBA.

\section{Phase 2}

This study adopted in-depth interviews to enable discussion of particular topics likely to provide richer and more complete data (Easterby-Smith et al., 2002). An understanding of unobservable objects can be achieved by conducting interviews and managing the responses and discussions (Patton, 1987). Even more importantly, using multiple or mixed research methods can enhance internal validity, thereby making triangulation possible.

Convenience and judgment sampling methods were selected, due to the exploratory nature of the research. All of the audio-recorded semi-structured interviews were transcribed and then analyzed systematically and iteratively. The 
audio recordings and transcripts were examined using Lincoln and Guba's (1986) inductive reasoning and Martin and Turner's (1986) comparative methods. Representative illustrations were used to show the consistency of views rather than to report them in exhaustive detail.

Based on the previous research and industry connections of the authors of this paper, 12 environmental science and engineering experts were selected as individual interviewees. As evident from their profiles in Table 2, five were environmental engineers, three were professors specializing in building energy, air quality, and waste water treatment, and four were consultants engaged in energy saving, water treatment, and waste management. The selection criteria for the experts included over 10 years of local area-relevant experience and knowledge.

Table 2. Profiles of Interviewed Experts

\begin{tabular}{cccccc}
\hline Code & $\begin{array}{c}\text { Educational } \\
\text { level }\end{array}$ & $\begin{array}{c}\text { Professional } \\
\text { qualification }\end{array}$ & $\begin{array}{c}\text { Years of } \\
\text { experience }\end{array}$ & $\begin{array}{c}\text { Number of } \\
\text { cities visited in } \\
\text { China's GBA }\end{array}$ & $\begin{array}{c}\text { Number of times } \\
\text { participated in } \\
\text { C\&E activities }\end{array}$ \\
\hline E1 & Master & 1 & 12 & 15 & 21 \\
E2 & Bachelor & 1 & 35 & 10 & 30 \\
E3 & Bachelor & 1 & 30 & 16 & 32 \\
E4 & Bachelor & 1 & 22 & 12 & 29 \\
E5 & Professor & 2 & 20 & 9 & 12 \\
E6 & Professor & 1 & 25 & 6 & 13 \\
E7 & Professor & 3 & 23 & 5 & 15 \\
E8 & Doctor & 2 & 30 & 4 & 18 \\
E9 & Master & 1 & 10 & 3 & 10 \\
E10 & Doctor & 1 & 10 & 5 & 9 \\
E11 & Doctor & 1 & 10 & 6 & 26 \\
E12 & Master & 1 & 24 & 4 & \\
\hline
\end{tabular}


The environmental mitigation reference framework with 11 categories and 59 reference methods resulting from Phase 1 was re-sorted according to three areas of expertise, namely energy-related technology, air or water technology, and management and administration methods (less technology). The first area included methods under the categories of energy efficiency or reduction, design, system, and renewable energy technology. The second area covered the categories of emission reduction, air quality, and water saving or recycling. The third area dealt with matters requiring less technology but more management and administrative skills, including green certification and awards, management or education, green purchasing, ecology, waste reduction, and recycling. In a pre-test, three experts reviewed the tables and a fact sheet summarizing the details of the C\&E centers in China's GBA. Pre-test feedback was used to refine the information for the formal interviews. The first fact sheet provided climatic data on the 11 cities in the GBA, including temperature, humidity, amount of rainfall, solar radiation, and wind speed. The other sheets indicated the geographical and hydrological situations near existing C\&E centers and centers under construction, plus site information, including built area, open area, and cyber links. The latter fact sheets were loaded onto three roll-up displays in the interviews to help the interviewees to understand the consolidated physical situations of the centers. The interviews were held in the interviewees' offices and were carried out by the project assistant.

\section{Data analysis}


The interviewed experts were briefed on the research aims and asked to review the three tables and factsheets in 10-15 minutes. The first question raised in the interview addressed the prioritization of mitigation measures found in the survey of $\mathrm{C} \& \mathrm{E}$ centers in developed countries. Other main questions were asked to solicit the interviewees' recommendation for extra mitigation measures and actions that would fit the context of the C\&E centers in China's GBA.

The respondents were encouraged to jot down any initial ideas or comments during their review. The interviews were carried out according to pre-outlined topics to enhance their validity and consistency. Finally, the results were used as references to supplement the initially established framework from the online search. Each interview lasted for 60 minutes.

The research staff analyzed the audio recordings with the transcripts and verified the correctness of the data. The study applied the content analysis method proposed by Miles and Huberman (1994) to process the transcripts through data reduction, then data display, and finally verification. The suggestions made in the interviews were circulated to the experts in the respective groups for agreement. Contradictory suggestions were removed. The results indicated a $91 \%$ consistency between the two rounds of data examination, surpassing the $80 \%$ reliability benchmark set by Latham and Saari (1984). 


\section{Results}

Table 3 shows that energy efficiency enhancement or energy reduction was the common environmental strategy deployed by the proactive centers, and that many of the sampled C\&E centers undertook these types of practice. Eleven methods in the category of "Energy Efficiency/Reduction" were identified, and the experts agreed that these practices should be performed. Although this category contained no core methods, the use of light-emitting diode (LED) and compact fluorescent lamp (CFL) technology was the most popular. Six selected C\&E centers, i.e., 54\%, had installed energy-efficient lighting. This was followed by the provision of occupancy sensors and the installation of control devices or cooling systems for heating, ventilation and air conditioning (HVAC) systems; about a third of the surveyed centers opted for these two methods.

Efforts to increase the energy efficiency of existing equipment, as observed in the hotel sector, were also observed (Chan, 2009; Teng et al., 2012; Mak et al., 2013; Lo et al., 2014). However, the installation of high-speed closing or rolling doors was a new energy-saving initiative unique to the C\&E centers. In addition, directors and green teams were found to be highly willing to apply renewable energy technology or green energy. Obtaining power from the green grid and using photovoltaic (PV) cells were popular methods. Nearly half of the sampled centers adopted this technology or related methods, which are seldom used in the hotel building sector.

Table 3. Environmental Methods (Energy-related Cluster)

\begin{tabular}{ccccccccccccccc} 
& A & B & C & D & E & F & G & H & I & J & K & Sum & $\%$ & Components \\
Energy Efficiency/Reduction & 1 & 1 & 1 & 1 & 1 & 1 & 1 & 1 & 1 & 1 & 1 & 11 & 100 & CC \\
\hline
\end{tabular}




\begin{tabular}{|c|c|c|c|c|c|c|c|c|c|c|c|c|c|c|c|}
\hline 1 & Solar control film & & & & & & & & & & & 1 & 1 & 9 & IC \\
\hline 2 & $\begin{array}{l}\text { Cooking equipment burners } \\
\text { designed with baffles }\end{array}$ & & & & & & 1 & & & & & & 1 & 9 & IC \\
\hline 3 & Ventilation system & 1 & & & & & & & & & & & 1 & 9 & IC \\
\hline 4 & LED and CFL technology & & 1 & 1 & 1 & 1 & & 1 & & 1 & & & 6 & 54 & $\mathrm{GC}$ \\
\hline 5 & $\begin{array}{l}\text { Occupancy sensors for } \\
\text { ON/OFF, stepped diming }\end{array}$ & 1 & & & & & 1 & & 1 & & & & 3 & 27 & $\mathrm{DC}$ \\
\hline 6 & Energy management system & & 1 & & & & 1 & & & & & & 2 & 18 & DC \\
\hline 7 & $\begin{array}{l}\text { HVAC/AHP motors and } \\
\text { control systems or } \\
\text { water-cooled chillers }\end{array}$ & & & 1 & & & & & 1 & & & 1 & 3 & 27 & DC \\
\hline 8 & High-speed doors & & & 1 & & & & & & & & & 1 & 9 & IC \\
\hline 9 & $\begin{array}{l}\text { Energy-efficient dishwashers } \\
\text { or boilers }\end{array}$ & & & & 1 & & 1 & & & & & & 2 & 18 & DC \\
\hline 10 & $\begin{array}{l}\text { Energy-efficient lifts or } \\
\text { escalators }\end{array}$ & & & & & & & & 1 & & & & 1 & 9 & IC \\
\hline 11 & Cogeneration or trigeneration & & & & & & & & & & 1 & & 1 & 9 & IC \\
\hline & Building Design \& System & 1 & 1 & & & & 1 & & & & & 1 & 4 & 36 & $\mathrm{GC}$ \\
\hline 12 & $\begin{array}{l}\text { Architecturally inspired } \\
\text { shading devices }\end{array}$ & 1 & & & & & & & & & & & 1 & 9 & $\mathrm{IC}$ \\
\hline 13 & $\begin{array}{l}\text { Cool roofs and light-defusing } \\
\text { windows }\end{array}$ & & 1 & & & & & & & & & & 1 & 9 & IC \\
\hline 14 & $\begin{array}{l}\text { Eaves and overhangs for air } \\
\text { conditioning }\end{array}$ & & & & & & 1 & & & & & & 1 & 9 & IC \\
\hline 15 & Direction of building & & & & & & 1 & & & & & & 1 & 9 & IC \\
\hline 16 & $\begin{array}{l}\text { Independent lighting zones/ } \\
\text { energy-efficient lighting }\end{array}$ & 1 & & & & & & & & & & 1 & 2 & 18 & DC \\
\hline 17 & Air-conditioning systems & 1 & & & & & & & & & & 1 & 2 & 18 & DC \\
\hline 18 & Radiant slabs & 1 & & & & & & & & & & & 1 & 9 & IC \\
\hline \multirow[t]{2}{*}{19} & PVC mitigation & & & & & & 1 & & & & & & 1 & 9 & IC \\
\hline & Renewable Energy & 1 & & 1 & & & & & 1 & 1 & 1 & 1 & 7 & 63 & $\mathrm{GC}$ \\
\hline 20 & Geo-thermal systems & & & & & & & & & 1 & & & 1 & 9 & $\mathrm{IC}$ \\
\hline 21 & $\begin{array}{l}\text { Solar garden partnership or } \\
\text { green grid source }\end{array}$ & 1 & & 1 & & & & & & & 1 & & 3 & 27 & $\mathrm{DC}$ \\
\hline 22 & PV systems & & & 1 & & & & & & 1 & 1 & & 3 & 27 & DC \\
\hline 23 & $\begin{array}{l}\text { Partnering with carbon } \\
\text { consultants }\end{array}$ & 1 & & & & & & & & & & 1 & 2 & 18 & DC \\
\hline \multirow[t]{2}{*}{24} & Solar hot water & 1 & & & & & & & & & & & 1 & 9 & IC \\
\hline & Total & 12 & 5 & 7 & 3 & 2 & 9 & 2 & 5 & 5 & 5 & 8 & 63 & & \\
\hline
\end{tabular}

Note: A - MCEC (Melbourne Convention Exhibition Center). B - LACC (Los Angeles Convention Exhibition Center). C - MCC (Minneapolis Convention Center). D - SDCC (San Diego Convention Center). E - ECL (ExCel Exhibition Center London). F - DCC (Darwin Convention Center). G - HKCEC (Hong Kong Convention and Exhibition Center). H - SE (Singapore Expo). I - MBEC (Messe Bremen Exhibition Center). J - ITCP (International Trade Center Paris). K - AWE (Asia World Expo). CC - core components (91\%-100\%). PC popular components $(71 \%-90 \%)$. GC - growing components $(31 \%-70 \%)$. DC - developing components $(11 \%-$ $30 \%)$. IC - innovative components (1\%-10\%).

Building energy use varies and is subject to the design of architecture and energy systems (U.S. Department of Energy, 2015). The statistics obtained in this study showed that during the planning stage of building and system design, the interest of C\&E center developers in energy-related saving initiatives was low; only about a third of the developers (four centers) approved such design initiatives. This finding can be 
attributed to budget constraints. The two most frequent energy-saving design directions taken were creating independent lighting zones and installing air conditioning.

As presented in Table 4, 45\% of the selected C\&E centers adopted environmental management methods aimed at emission reduction and indoor air quality improvement. C\&E centers could consider encouraging staff and visitors to use public transportation and adopting materials with low levels of volatile organic compounds (VOCs), as these two methods have the greatest impact in the two categories of emissions reduction and air quality.

In the water-saving or recycling category, about half of the sampled centers used relevant methods. Water-saving irrigation systems are a key measure in centers with surrounding greenery. Other methods used were low-pressure units in toilets, water-efficient kitchen facilities, water treatment facilities, and drought-tolerant plants.

As shown in Table 5, the studied C\&E centers received certification and awards for their green efforts and had recruited dedicated teams to plan, design, and manage environmental matters. However, the category of green purchasing seemed to receive the least attention from operators; only 3 of the 11 selected centers reported actions in this category. It is worth noting, however, that three centers that did not report green 
purchasing activities came up with ocean-friendly/sustainable menus with ecological diversity concerns under the "Bio-diversity and Habitat Restoration" category.

Table 4. Environmental Methods (Air- and Water-related Cluster)

\begin{tabular}{|c|c|c|c|c|c|c|c|c|c|c|c|c|c|c|c|}
\hline & & A & $\mathrm{B}$ & $\mathrm{C}$ & $\bar{D}$ & $\mathrm{E}$ & $\mathrm{F}$ & $\mathrm{G}$ & $\mathrm{H}$ & $\mathrm{I}$ & $\mathrm{J}$ & $\mathrm{K}$ & Sum & $\%$ & Components \\
\hline & Emissions Reduction & & 1 & 1 & & & 1 & & & 1 & & 1 & 5 & 45 & $\mathrm{GC}$ \\
\hline 25 & Transportation & & 1 & 1 & & & & & & 1 & & & 3 & 27 & $\mathrm{DC}$ \\
\hline 26 & $\begin{array}{l}\text { Installation of gas-boosted } \\
\text { hot water plant }\end{array}$ & & & & & & 1 & & & & & & 1 & 9 & IC \\
\hline 27 & Dim-it and no-car day & & & & & & & & & & & 1 & 1 & 9 & IC \\
\hline 28 & $\begin{array}{l}\text { Tree planting and indoor } \\
\text { plant use }\end{array}$ & & & & & & & & & & & 1 & 1 & 9 & IC \\
\hline 29 & Low $\mathrm{NO}_{x}$ and $\mathrm{CO}_{2}$ burners & & 1 & & & & & & & & & & 1 & 9 & IC \\
\hline & Air Quality & 1 & & & 1 & & 1 & 1 & & & & 1 & 5 & 45 & $\mathrm{GC}$ \\
\hline 30 & Air-related certification & & & & 1 & & & & & & & 1 & 2 & 18 & $\mathrm{DC}$ \\
\hline 31 & Low VOC items & 1 & & & & & 1 & 1 & & & & & 3 & 27 & $\mathrm{DC}$ \\
\hline 32 & $\begin{array}{l}\text { Small fan filters with UV } \\
\text { rays }\end{array}$ & & & & & & 1 & & & & & & 1 & 9 & $\mathrm{IC}$ \\
\hline & Water Saving/ Recycling & 1 & 1 & 1 & 1 & & 1 & 1 & & & & & 6 & 54 & $\mathrm{GC}$ \\
\hline 33 & Low GPF units for toilets & & 1 & & 1 & & & & & & & & 2 & 18 & $\mathrm{DC}$ \\
\hline 34 & Leak-preventing models & & 1 & & & & & & & & & & 1 & 9 & $\mathrm{IC}$ \\
\hline 35 & $\begin{array}{l}\text { Water-efficient kitchen } \\
\text { facilities }\end{array}$ & & & 1 & 1 & & & & & & & & 2 & 18 & DC \\
\hline 36 & Sensor faucets & & & & & & & 1 & & & & & 1 & 9 & IC \\
\hline 37 & $\begin{array}{l}\text { Water-saving irrigation } \\
\text { system }\end{array}$ & & 1 & & 1 & & 1 & & & & & & 3 & 27 & $\mathrm{DC}$ \\
\hline 38 & Drought-tolerant plants & & 1 & & 1 & & & & & & & & 2 & 18 & $\mathrm{DC}$ \\
\hline 39 & Rainwater storage system & & 1 & 1 & & & & & & & & & 2 & 18 & DC \\
\hline 40 & $\begin{array}{l}\text { Chemical-free water } \\
\text { treatment technology/ } \\
\text { water treatment }\end{array}$ & 1 & 1 & & & & & & & & & & 2 & 18 & $\mathrm{DC}$ \\
\hline & Total & 4 & 10 & 5 & 7 & 0 & 7 & 4 & 0 & 2 & 0 & 5 & 42 & & \\
\hline
\end{tabular}

Note: A - MCEC (Melbourne Convention Exhibition Center). B - LACC (Los Angeles Convention Exhibition Center). C - MCC (Minneapolis Convention Center). D - SDCC (San Diego Convention Center). E - ECL (ExCel Exhibition Center London). F - DCC (Darwin Convention Center). G - HKCEC (Hong Kong Convention and Exhibition Center). H - SE (Singapore Expo). I - MBEC (Messe Bremen Exhibition Center). J - ITCP (International Trade Center Paris) K - AWE (Asia World Expo). CC - core components (91\%-100\%). PC popular components $(71 \%-90 \%)$. GC - growing components $(31 \%-70 \%)$. DC - developing components $(11 \%-$ $30 \%)$. IC - innovative components $(1 \%-10 \%)$.

Finally, the category on solid waste handling ranked as the third key direction in environmental initiatives of the centers, with a recorded $72 \%$ participation by the 11 studied centers. The most-reported methods are contracted recycling (54\%), followed by food waste composting (45\%) and waste sorting (36\%). On average, $32 \%$ of the categorized items under "Waste reduction and recycling" were reported by the surveyed centers. 
Table 5. Environmental Methods (Management and Administration Cluster)

\begin{tabular}{|c|c|c|c|c|c|c|c|c|c|c|c|c|c|c|c|}
\hline & & $\mathrm{A}$ & $\mathrm{B}$ & $\mathrm{C}$ & $\mathrm{D}$ & $\mathrm{E}$ & $\mathrm{F}$ & $\mathrm{G}$ & $\mathrm{H}$ & $\mathrm{I}$ & $\mathrm{J}$ & $\mathrm{K}$ & Sum & $\%$ & Components \\
\hline & Certification/Award & 1 & 1 & 1 & 1 & 1 & 1 & 1 & 1 & 1 & 1 & 1 & 11 & $\begin{array}{c}10 \\
0\end{array}$ & $\mathrm{CC}$ \\
\hline 41 & $\begin{array}{l}\text { LEED/ISO14001/ } \\
\text { 20121/Green standard/ Green } \\
\text { Globe }\end{array}$ & & & 1 & 1 & 1 & 1 & 1 & 1 & 1 & 1 & & 8 & 72 & $\mathrm{PC}$ \\
\hline \multirow[t]{2}{*}{42} & $\begin{array}{l}\text { Award-Sustainability/ Star } \\
\text { rating }\end{array}$ & 1 & 1 & & 1 & 1 & 1 & & 1 & & 1 & 1 & 8 & 72 & $\mathrm{PC}$ \\
\hline & $\begin{array}{l}\text { Management and } \\
\text { Education }\end{array}$ & 1 & 1 & 1 & 1 & 1 & 1 & 1 & 1 & 1 & 1 & 1 & 9 & $\begin{array}{c}10 \\
0\end{array}$ & $\mathrm{CC}$ \\
\hline 43 & Green team & 1 & & 1 & 1 & & & & 1 & & & & 4 & 36 & $\mathrm{GC}$ \\
\hline 44 & Trained staff & & 1 & 1 & 1 & 1 & 1 & 1 & & 1 & & 1 & 8 & 72 & $\mathrm{PC}$ \\
\hline \multirow[t]{2}{*}{45} & $\begin{array}{l}\text { Stakeholder events, social } \\
\text { media }\end{array}$ & & 1 & 1 & & 1 & & & & & & & 3 & 27 & $\mathrm{DC}$ \\
\hline & Green Purchasing & & 1 & & 1 & & 1 & & & & & & 3 & 27 & $\mathrm{DC}$ \\
\hline 46 & Use local or organic food & & 1 & & 1 & & 1 & & & & & & 3 & 27 & $\overline{\mathrm{DC}}$ \\
\hline 47 & $\begin{array}{l}100 \% \text { free-range } \\
\text { hormone-free, grass-fed food }\end{array}$ & & 1 & & & & & & & & & & 1 & 9 & $\mathrm{IC}$ \\
\hline 48 & $\begin{array}{l}\text { Biodegradable and recyclable } \\
\text { cleaning agents, paper, } \\
\text { solvents }\end{array}$ & & 1 & & 1 & & 1 & & & & & & 3 & 27 & $\mathrm{DC}$ \\
\hline 49 & $\begin{array}{l}\text { Replace paper towels with } \\
\text { efficient models }\end{array}$ & & 1 & & & & & & & & & & 1 & 9 & IC \\
\hline 50 & $\begin{array}{l}\text { Reduce single-use } \\
\text { disposables }\end{array}$ & & 1 & & 1 & & & & & & & & 2 & 18 & $\mathrm{DC}$ \\
\hline 51 & $\begin{array}{l}\text { Require contractor's } \\
\text { adherence to green } \\
\text { practice/partnership }\end{array}$ & & & & 1 & & 1 & & & & & & 2 & 18 & $\mathrm{DC}$ \\
\hline \multirow[t]{2}{*}{52} & $\begin{array}{l}\text { Energy-efficient star rating } \\
\text { appliances }\end{array}$ & & & & & & 1 & & & & & & 1 & 9 & IC \\
\hline & $\begin{array}{l}\text { Bio-diversity and Habitat } \\
\text { Restoration }\end{array}$ & 1 & & & & & & 1 & & & & 1 & 3 & 27 & DC \\
\hline \multirow[t]{2}{*}{53} & $\begin{array}{l}\text { Ocean-friendly (and carbon } \\
\text { care) sustainable menu }\end{array}$ & 1 & & & & & & 1 & & & & 1 & 3 & 27 & $\mathrm{DC}$ \\
\hline & $\begin{array}{l}\text { Waste Reduction and } \\
\text { Recycling }\end{array}$ & 1 & 1 & 1 & 1 & 1 & 1 & 1 & & & & 1 & 8 & 72 & $\mathrm{PC}$ \\
\hline 54 & $\begin{array}{l}\text { Waste storage of sorting } \\
\text { system }\end{array}$ & & 1 & 1 & & & 1 & & & & & 1 & 4 & 36 & GC \\
\hline 55 & $\begin{array}{l}\text { Composting of food and } \\
\text { landscape waste/wormery }\end{array}$ & 1 & 1 & & 1 & 1 & & 1 & & & & & 5 & 45 & $\mathrm{GC}$ \\
\hline 56 & $\begin{array}{l}\text { Staff collect food scraps to } \\
\text { feed hogs/for donation }\end{array}$ & & & 1 & 1 & & & 1 & & & & & 3 & 27 & DC \\
\hline 57 & $\begin{array}{l}\text { Use of reusable/recyclable } \\
\text { content (platters, low PVC) }\end{array}$ & 1 & & & & & 1 & & & & & & 2 & 18 & DC \\
\hline 58 & $\begin{array}{l}\text { Recycling contractors and } \\
\text { targets (including copper, } \\
\text { lightbulbs, cartridges, } \\
\text { cooking oil, compostable } \\
\text { food containers) }\end{array}$ & & & 1 & 1 & 1 & 1 & 1 & & & & 1 & 6 & 54 & $\mathrm{GC}$ \\
\hline \multirow[t]{2}{*}{59} & $\begin{array}{l}\text { Donation of lost and found } \\
\text { items or discarded items }\end{array}$ & & & & 1 & & & & & & & & 1 & 9 & IC \\
\hline & Total & 9 & 14 & 10 & 16 & 9 & 14 & 10 & 5 & 4 & 4 & 9 & 102 & & \\
\hline
\end{tabular}

Note: A - MCEC (Melbourne Convention Exhibition Center). B - LACC (Los Angeles Convention Exhibition Center). C MCC (Minneapolis Convention Center). D - SDCC (San Diego Convention Center). E - ECL (ExCel Exhibition Center London). F - DCC (Darwin Convention Center). G - HKCEC (Hong Kong Convention and Exhibition Center). H - SE (Singapore Expo). I - MBEC (Messe Bremen Exhibition Center). J - ITCP (International Trade Center Paris). K - AWE (Asia World Expo). CC core components $(91 \%-100 \%)$. PC - popular components $(71 \%-90 \%)$. GC - growing components $(31 \%-70 \%)$. DC developing components $(11 \%-30 \%)$. IC - innovative components $(1 \%-10 \%)$.

Strategically, obtaining a green certificate and energy reduction were equally the two most prioritized directions for environmental mitigation reported by the proactive 
green management $C \& E$ centers. The third (72\%) and fourth priorities (54\%) in terms of frequency count of adoption were waste reduction and water saving. These two were followed by three other initiatives, namely the use of renewable energy, emission reduction, and air quality improvement, which had equal weights (45\%).

Furthermore, most of the methods in all three clusters classified as innovative components were adopted by only one of the selected centers. This observed phenomenon implies either that the influence of local factors is great or that few of the selected centers were willing to attempt innovative or unconventional methods. The latter was perhaps motivated by the scoring design or assessment criteria set in the LEED green certification process. As shown in Tables 3 and 4, the study identified 14 and 7 innovative methods in the energy-related and air and water categories, respectively. Both accounted for $58 \%-43 \%$ of the methods in these two categories. It is thus easier for $\mathrm{C} \& \mathrm{E}$ centers to find and achieve innovation in these two categories, compared with the four innovative methods $(22 \%)$ in the management and waste category.

\section{Environmental experts'view}

In the second stage, interviewees disclosed that among these environmental methods for sustainable development, the provision of clean and stable energy delivery, reliable water supply, and air quality improvement should be prioritized by the exhibition industry in most cities. 


\section{Additions to the energy-related category}

The incorporation of a district cooling system into the framework was suggested for the energy-saving category. Given the hot climate of China's GBA, with the hot season lasting for an average of 10 months per year, and the huge indoor space of C\&E centers, experts agreed that HVAC systems are responsible for the highest power consumption of all center facilities. They also agreed that the use of a water-cooling method for HVAC systems in the GBA's C\&E centers from natural water bodies such as rivers, lakes, or the sea offers a promising alternative to cooling chillers in the area. The construction of large water storage and pumping facilities is recommended as an alternative reference framework.

The interviewees in this group reported several critical views on the use of renewable technologies in $\mathrm{C} \& \mathrm{E}$ centers. To ensure stable energy delivery, the interviewees suggested that the centers make more use of renewable energy devices (e.g. PV energy, power storage, and fuel cells); such devices supplement energy and serve as a backup for or link with a municipal power grid system. The interviewees also mentioned that the vast area of roof surfaces and side façades of C\&E centers and nearby open ground provides a relatively large surface for receiving solar energy. In addition, the price of PV panels has declined immensely, and China has become a major producer of such equipment. Furthermore, the installation of PV-related facilities has been adopted in many exhibition centers, such as Minneapolis 
Convention Center, Los Angeles Convention Center, and San Diego Convention Center. In view of these positive factors and their costs and benefits, a related study should be carried out immediately and incorporated into the framework developed here as an action-oriented addition.

One expert added, "Macau is located along the coast, and a large-scale wind turbine could also provide an additional or major power supply." Another interviewee remarked that, "Mainland China is the major renewable energy facilities supplier in the global market and offers very competitive prices in the current market. Indeed, mainland Chinese companies have already built such large-scale wind farms in Nan O and nearby coastal areas and should have adequate experience in implementing the said technology." During the interviews, a study of wind power potential was also proposed as a measure for implementation by proactively green $C \& E$ centers.

The energy experts agreed that hybrid solar-wind systems are also a mature technology that can provide electricity for lighting and deliver surplus energy to the grid system or central storage. Given the (usually) large areas of independent exhibition halls and numerous lighting poles surrounding exhibition venues, most C\&E centers have adequate space for installing such facilities. The interviewees agreed on including the potential contribution made by a study of hybrid solar-wind panels in the reference framework. 
In addition, energy experts advised that a specific energy consumption database be established to benchmark energy consumption in these C\&E centers. The design of such a database, including the data collection template, should be carried out by building energy professionals and professors from an independent institute. Regular benchmarking exercises allow operators to strive for improvement based on comparative results and to form a means of selecting yardsticks in the reference framework.

Additions to the air and water category

One interviewee pointed out that the low quality of indoor air stemmed from the VOCs of interior materials, mainly derived from the painting and adhesive agents used in exhibition booths. In addition, the high density of visitors and weak ventilation may increase $\mathrm{CO}_{2}$ levels in venues. The dust created during booth set-up and the carbon emissions intake from the transport near such venues, as some centers are constructed along main highways with heavy traffic, may exacerbate these problems.

In terms of air quality improvement, another expert said that, "The exhibition halls could consider installing cyclonic dust filters to improve air quality, as implemented by Darwin Convention Center. Cleaned air was discharged from the machine after being passed through filters and an ultraviolet light system." 
As air pollutants are almost unobservable, one expert noted that monitoring indoor air quality is necessary to ensure that air filtration facilities are effective. All of the other experts supported the set-up of a monitoring device, which can serve as an addition to the reference framework.

Although China's GBA is rich in natural water resources, one expert indicated that Macau and Zhuhai are affected by the intrusion of seawater for several days each year, during which water becomes saline. He suggested building a large water storage tank or tower to mitigate the resulting water shortage problems. He added that the exhibition hall roof surface and surrounding areas could also provide relatively large rainwater catchment areas and that water could be stored either underground or above ground. Finally, all of the interviewees proposed that floating desalination plants be constructed to provide an emergency water supply as an addition to the reference framework.

\section{Additions to the administration and management category}

Although C\&E centers in Hong Kong carry out many green methods to support environmental conservation, room for improvement still exists. "Given the shortage of landfill area and that existing landfill sites in the city are almost full, it is necessary to focus on or direct more effort toward reducing solid waste," an expert said. He recommended that future designs for $\mathrm{C} \& \mathrm{E}$ centers should consider allowing space for the driving in and out of container trucks, which may increase the reuse of 
construction materials for display booths in other venues.

Another expert mentioned that the large quantities of indoor boxes and plastic cups used by $\mathrm{C} \& \mathrm{E}$ centers in mainland China pose another challenge. "Especially in southern China, most meal boxes are made with foam, whereas some centers in the Yangtze River area are already using more environmentally friendly materials like bamboo to manufacture paper cups." The interviewee added that much packaging waste arises from the delivery processes of logistics companies, and suggested that centers partner with logistics firms to think of ways to mitigate this impact.

In terms of environmental management systems and reporting, one interviewee mentioned that "most existing corporations have combined social responsibility and environmental conservation. However, this has always overshadowed actions or reporting in some important areas of environmental conservation. Disaggregating these two items may give outsiders a clearer understanding and facilitate subsequent monitoring of corporations' efforts in these two areas." The above four ideas were endorsed by all of the interviewees in this group.

\section{Barriers to implementing the experts'suggestions}

The experts agreed that the realization of some innovative and effective initiatives requires intensive capital, advanced technology, and a lengthy duration of commitment. Center managers are hired on contractual terms for several years or 
fewer, and they may not be interested in such projects, thereby constraining centers' initiatives. Alternatively, some green teams may put tremendous effort into initiating such mitigating measures. Thus, offering incentives to motivate teams to pursue innovation or recognizing their contribution by granting marks for such innovation in environmental improvement assessment exercises are noteworthy recommendations.

An expert supported the above perspective and shared the following views.

"To examine the feasibility of the innovative ideas in depth, green teams could use consultants or liaise with the government in hiring consultants to evaluate potential renewable energy and water options. It may take a long time to process suggestions. At the same time, staff and managers should also learn about the technology suggested during the consultation process, such as the use of an anemometer to measure incoming solar radiation and dust tracking to monitor PM2.5. Great effort and involvement are necessary to realize innovative ideas." Table 6 is a summary of the views and suggestions made by the experts.

In a nutshell, one of the objectives of this study was to synthesize a reference framework of environmental mitigation practices for $C \& E$ centers. The aggregation and classification of the identified environmental methods according to environmental categories form a synergetic bundle of criteria for the reference of $\mathrm{C} \& \mathrm{E}$ operators and for initiatives undertaken by $\mathrm{C} \& \mathrm{E}$ centers in the 11 cities. 
Table 6. Experts' Views and Suggestions

\begin{tabular}{|c|c|}
\hline \multirow{8}{*}{$\begin{array}{l}\text { Additions to the } \\
\text { energy-related category }\end{array}$} & Incorporation of district cooling systems \\
\hline & Water cooling as a promising alternative for cooling chillers \\
\hline & $\begin{array}{l}\text { Use of renewable energy such as PV energy, power storage, and fuel } \\
\text { cells as backup for or link with the municipal power grid system }\end{array}$ \\
\hline & Vast surface of C\&E centers can be utilized for solar energy \\
\hline & $\begin{array}{l}\text { PV-related facilities should be adopted due to the immense drop in the } \\
\text { price of PV devices }\end{array}$ \\
\hline & Large-scale wind turbines could be considered \\
\hline & $\begin{array}{l}\text { Hybrid solar-wind systems are a mature technology that could be } \\
\text { considered }\end{array}$ \\
\hline & $\begin{array}{l}\text { A database of energy consumption could be developed for } \\
\text { benchmarking }\end{array}$ \\
\hline \multirow{4}{*}{$\begin{array}{l}\text { Additions to the air and } \\
\text { water category }\end{array}$} & Installation of cyclonic dust filters to improve air quality \\
\hline & Installation of devices for monitoring air quality \\
\hline & $\begin{array}{l}\text { Building large water storage tanks or towers to address the occasional } \\
\text { intrusion of seawater }\end{array}$ \\
\hline & Construction of floating desalination plants \\
\hline \multirow{4}{*}{$\begin{array}{l}\text { Additions to the } \\
\text { administration } \\
\text { management category }\end{array}$} & $\begin{array}{l}\text { Creating space for the driving in and out of container trucks to increase } \\
\text { the reuse of construction materials for display booths }\end{array}$ \\
\hline & $\begin{array}{l}\text { Using environmentally friendly materials such as manufactured bamboo } \\
\text { paper cups }\end{array}$ \\
\hline & Finding ways to reduce packaging waste from the delivery process \\
\hline & $\begin{array}{l}\text { Combining corporate social responsibility and environmental } \\
\text { conservation for better understanding and monitoring }\end{array}$ \\
\hline \multirow[t]{3}{*}{$\begin{array}{l}\text { Barriers to implementing } \\
\text { the experts' suggestions }\end{array}$} & $\begin{array}{l}\text { Realizing innovative and effective methods requires intensive capital, } \\
\text { advanced technology, and lengthy duration of commitment }\end{array}$ \\
\hline & $\begin{array}{l}\text { C\&E center managers may be hired on contractual terms for several } \\
\text { years and may not be interested in those initiatives }\end{array}$ \\
\hline & Green teams are advised to take care of relevant issues \\
\hline
\end{tabular}

The synergetic sorting of environmental directions based on the initiatives of

these 11 centers represents a relatively objective assessment framework in the industry.

The experts' views and suggestions further verified the mitigation methods in forming

a solid framework and foundation for the industry to make decisions on what types of

mitigation methods should be used for the benefit of C\&E centers and the broad

environment as a whole. Academic researchers can refer to the framework to advance

research in this area. 


\section{Conclusion}

Environmental problems and potential remedies are major concerns of modern societies. Efforts must be made by both corporations and individuals to improve environmental quality on both the macro- and the micro-scale. In recognition the urgent need and lack of holistic environmental mitigation efforts in the C\& E industry (Chen, 2009; Lu, \& Cai, 2011; Spiller 2002), this investigation examined the environmental methods undertaken by 11 green-certified C\&E centers in developed areas as reported online, which were further validated by a group of 12 experts in environmental science and engineering at the second phase; the 59 methods were generalized into 11 categories under an environmental mitigation methods framework. Theoretically, previous environmental studies in MICE industry have been focused on single venue (e.g., Chen 2009). Their implication could potentially be limited. The current investigation provides a holistic framework for the MICE industry to undertake any environmental mitigation.

Regarding the practical implications, the results provide insights for managers into formulating environmental strategies and actions. Of the 59 mitigation methods, 25 innovative methods were identified for reference by industry practitioners in the future. This framework provides operators and planners of $C \& E$ centers with an informative reference point for devising and designing environmental alleviation methods, especially for centers in China's GBA and the current environmental strategies of industry players. Existing C\&E centers may balance the commitment 
required for and cost incurred by the adoption of different mitigation methods against the benefits of reducing their negative environmental impact; hence, putting mitigation methods into practice is a challenge for $C \& E$ centers.

The resulting framework identified in this research serves as a useful tool to identify the suitable mitigation method for C\&E centers. Future research could enhance the current framework through focusing on the weighting of these mitigation methods or categories in the environmental assessment process. The research result was based on 11 GCC\&E centers in China in 2016. A longitudinal research could be beneficial as it could have better understanding of the future progress and diffusion of mitigation methods. Data collection could be extended to C\&E centers in developed nations using languages other than English to achieve a globally representative status. 


\section{References}

Asia World Expo. Caring for the environment. Retrieved November 14, 2017, from http://www.asiaworld-expo.com/about-us/corporate-social-responsibility-1/_cari ngforenvironment.

Becken, S. (2002). Tourism and transport in New Zealand - Implications for energy use. TRREC Report, no. 54, July, Lincoln University.

Becken, S., Simmons, D.G., \& Frampton, C. (2003). Energy use associated with different travel choices. Tourism Management, 24(3), 267-277.

Bohdanowicz, P., Zientara, P., \& Novotna, E. (2017). International hotel chains and environmental protection: An analysis of Hilton's we care! programme (Europe, 2006-2008). Journal of Sustainable Tourism, 19(7), 797-816.

Bramwell, B., \& Lane, B. (2012). Towards innovation in sustainable tourism research? Journal of Sustainable Tourism, 20(1), 1-7.

Carlsen, J., Liburd, J.J., Edwards, D., \& Forde, P. (2008). The Importance of Networks for Innovation in Sustainable Tourism. Best Education Network. Innovations for Sustainable Tourism: International Case Studies. University of Southern Denmark.

Carruthers, C.P., \& Busser, J.A. (2000). A qualitative outcome study of Boys and Girls Club program leaders, club members, and parents. Journal of Park and Recreation Administration, 14(4), 1-20.

Chan, W., \& Mak, B. (2005). An analysis of the environmental reporting structures of selected European airlines. International Journal of Tourism Research, 7, 249-259.

Chan W. (2009). Environmental methods for hotels' environmental management systems. ISO 14001. International Journal of Contemporary Hospitality Management, 21(5), 532-560.

Chen, K. (2009). Research report on Chinese Convention and Exhibition Industry. Business Community. March 24, 2009.

Darwin Convention Center. (2017). Sustainability initiatives. Retrieved November 17, 2017, from https://www.darwinconvention.com.au/sustainability-initiatives.html.

Decrop, A. (1999). Triangulation in qualitative tourism research. Tourism Management, 20(1), 157-161. 
Department of Trade in Services (2016). China Convention and Exhibition Industry Development Report, Ministry of Commerce, China.

Ding, K.C. (2008). Sustainable construction - The role of environmental assessment tools. Journal of Environmental Management, 86, 451-464.

Dubois, G., \& Ceron, J.P. (2006). Tourism and climate change: Proposals for a research agenda. Journal of Sustainable Tourism 14(4), 399-415.

Easterby-Smith, M., \& Thorpe, R. (1991). Management research. London: Sage.

Easterby-Smith, M., Thorpe, R., \& Lowe, A. (2002). Management research: An introduction. London: Sage.

ExCel Exhibition Center London. (2017). Sustainability. Retrieved November 15, 2017, from https://www.excel.london/sustainability.

Fang, Y. (2017). Cooperation is key to building China's Bay Area. China Business Knowledge@CUHK. Retrieved October 18, 2017, from http://www.bschool.cuhk.edu.hk/faculty/cbk/article.aspx?id=17911957.

Filimonau, V., Dickinson, J.E., Robbins, D., \& Reddy, M.V. (2011). A critical review of methods for tourism climate change appraisal: Life cycle assessment as a new approach. Journal of Sustainable Tourism, 19(3), 301-324.

http://dx.doi.org/10.1080/09669582.2010.527345.

Green Meeting Industry Council. (n.d.) Why sustainability? Retrieved November 2, 2008, from http://greenmeetings.info/Why We Do It.html.

Grossling. S., \& Svensson, P. (2016). Tourist perceptions of climate change: a study of international tourists in Zanzibar. Current Issues in Tourism, 9 (4 \& 5), 419-435.

Guangzhou Import and Export Fair Complex. (2017). Introduction to CFTC. Retrieved November 15, 2017, from http://www.ciefc.com/pages_en/info.aspx?catid=296302.

Hong Kong Convention and Exhibition Center. (2017). Sustainability commitment. Retrieved November 12, 2017, from https://www.hkcec.com/en/sustainability-commitment. 
Hoyer, K.G., \& Naess, P. The ecological traces of growth: Economic growth, liberalization, increased consumption-and sustainable urban development? Journal of Environmental Policy \& Planning, 3(3), 177-192.

International Trade Center Paris. (2017). A comprehensive range of associated facilities. $\quad$ Retrieved November 10, 2017, from https://www.itc-paris.com/en/infrastructures-itc-paris-roissy-cdg-business-conve ntion-complex.

Kay, A.L.K. (2005) China's convention and exhibition center boom,

Journal of Convention \& Event Tourism, 7(1), 5-22, DOI: 10.1300/J452v07n01_02.

Kelly, J., \& Williams, P.W. (2007). Modelling tourism destination energy consumption and greenhouse gas emissions: Whistler, British Columbia, Canada. Journal of Sustainable Tourism, 15(1), 67-90.

Latham, G.P., \& Saari, L.M. (1984). Do people do what they say? Further studies on the situational interview. Journal of Applied Psychology, 69, 569-573.

Law, C., (Ed.). (2004). Urban tourism: The visitor economy and the growth of large cities. New York: Continuum.

Lincoln, Y.S., \& Guba, E.G. (1986). But is it rigorous? Trustworthiness and authenticity in naturalistic evaluation. New Directions for Evaluation. N30, 73-84.

Lo, J.Y., Chan, W., \& Zhang, C.X. (2013). Tools for benchmarking and recognizing hotels' green effort-environmental assessment methods and eco-labels. Journal of China Tourism Research, 10(2), 165-185.

Los Angeles Convention Center. (2017). Environmental sustainability. Retrieved November 10, 2017, from https://www.lacclink.com/about/green-initiatives.

Lu, T.Y., \& Cai, L.P. (2011). An analysis of image and loyalty in convention and exhibition tourism in China. Event Management, 15(1), 37-48.

Mak, B., \& Chan, W. (2006). Environmental reporting of airlines in the Asia Pacific region. Journal of Sustainable Tourism, 14(6), 618-628.

Meeting Strategies Worldwide. (2006). What is a green meeting? Retrieved May 1, 2008, from http://www.meetingstrategiesworldwide.com/files/articles/mswwwwhatgreenmtg s.pdf. 
Melbourne Convention Exhibition Center. (2017). Why choose MCEC. Retrieved November 10, 2017, from http://mcec.com.au/plan-an-event/why-choose-mcec/.

Messe Bremen Exhibition Center. (2017). A green vision for the future. Retrieved October 10, 2017, from http://www.bremen-tourism.de/messe-bremen-3.

Miles, M.B., \& Huberman, A.M. (1994). Qualitative Data Analysis: An expanded sourcebook. London: Sage.

Minneapolis Convention Center. (2017). Sustainability. Retrieved December 15, 2017, from

https://www.minneapolis.org/minneapolis-convention-center/about/sustainability/

Mok, K.M., Wong, H., \& Fan, X.J. (2011). Water resource management of Macao SAR to tackle its sea water intrusion problem, Asian and Pacific Coasts 2011:1402-1409. Proceeding of the Sixth International Conference on Asian and Pacific Coasts. Retrieved November 15, 2017, from https://books.google.com.hk/books?id=rl66CgAAQBAJ\&pg=PA1402\&lpg=PA1 $402 \& \mathrm{dq}=$ saline + water + macau\&source $=$ bl\&ots $=-S 73 \_$Nclb8\&sig=DWrj4XJHZN zH6y7uYnUaxF8Ojms\&hl=zh-CN\&sa=X\&ved=0ahUKEwjM69DrrPnVAhUBN ZQKHb30C18Q6AEIPTAG\# $\mathrm{v}=$ onepage \&q=saline $\% 20$ water\%20macau\&f=false.

Mugge, R., \& Dahl, D.W. (2013). Seeking the ideal level of design newness: Consumer response to radical and incremental product design. Journal of Product Innovation Management, 30(S1), 34-47.

Patton, M. (1987). How to use qualitative methods in evaluation. California: Sage.

San Diego Convention Center. (2017). Meetings. Retrieved October 15, 2017, from https://visitsandiego.com/facility/green-meetings.

Scott, D., Peeters, P., \& Gossling, S. (2010). Can tourism deliver its "aspirational" greenhouse gas emission reduction targets? Journal of Sustainable Tourism, 18(3), 393-408. http://dx.doi.org/10.1080/09669581003653542.

Singapore Convention and Exhibition Expo. (2017). Max Atria@ Singapore EXPO wins BCA Green Mark Platinum Award. Retrieved December 15, 2017, from https://www.newswire.com/max-atria-singapore-expo-wins-bca/114297.

Song, M., \& Thieme, J. (2008). The role of suppliers in market intelligence gathering for radical and incremental innovation. The Journal of Product Innovation Management, 26(1), 43-57. 
Spiller, J. (2002). History of convention tourism. Convention Tourism: International Research and Industry Perspectives, 3-20. Haworth Hospitality Press.

Teng, C.C., Horng, J.S., Hu, M.L., Chien, L.H., \& Shen, Y.C. (2012). Developing energy conservation and carbon reduction indicators for the hotel industry in Taiwan. International Journal of Hospitality Management, 31, 199-208.

UFI. (2014). Global Exhibition Industry Statistics. The Global Association of the Exhibition Industry. Retrieved March 12, 2014, from http://www.ufi.org/wp-content/uploads/2016/01/2014_exhibiton_industry_statisti cs_b.pdf.

UFI. (2015). Global Exhibition Barometer. 14th edition. Retrieved January 12, 2015, from http://www.clcvecta.nl/content/user/files/public_documents/ufi-global-exhibition -barometer-january-2015.pdf.

UFI. (2016). The UFI Report on Best Practices in Sustainability. 2012: Best Sustainable Development Strategy. Retrieved October 15, 2016, from http://www.ufi.org/wp-content/uploads/2016/10/UFI_Best_Practices_In_Sustaina bility_Report.pdf.

UFI. (2017). Global Exhibition Barometer. 19th Edition. The Global Association of the Exhibition Industry. Retrieved July 10, 2017, from http://www.cbbs.hr/wp-content/uploads/2017/08/UFI_Global_Exhibition_Barom eter_report19.pdf.

U.S. Building Council. (2017). Healthy, Green Buildings. Retrieved October 15, 2017, from https://new.usgbc.org/.

U.S. EPA. (2000). A method for quantifying environmental indicators of selected leisure activities in the United States. Washington, DC: Office of Policy, Economics, and Innovation, US Environmental Protection Agency.

U.S. Department of Energy (2015) Quadrennial technology review an assessment of energy technologies and research opportunities: Chapter 5: Increasing efficiency of building systems and technologies. Retrieved July 10, 2018, from https://www.energy.gov/sites/prod/files/2017/03/f34/qtr-2015-chapter5.pdf.

Walsh, K. (2003). Qualitative research: Advancing the science and practice of hospitality. Cornell Hotel and Restaurant Administration Quarterly, 44(2), 66-74. 